\title{
Effect of some water sources on growth performance of Nile tilapia (Oreochromis niloticus) and Grey mullet (Mugil cephalus)
}

\author{
Mohamed, T. Shehab El-Din ${ }^{1}$, Ahmed, F. El-Bab ${ }^{2}$; Mohamed, A. Mostafa ${ }^{2}$, \\ Ibrahim, M. Samra ${ }^{2}$ and Amal, S. Hassan ${ }^{2}$ \\ 1- Central Laboratory for Aquaculture Research, Sakha Aquaculture Research Unit. \\ Fish diseases Department, Egypt. \\ 2- Central Laboratory for Aquaculture Research, Agriculture Research Center. Fish \\ production Department, Egypt.
}

\section{ABSTRACT}

The present experiment was carried out to study the impact of water sources on cultured Nile tilapia; Oreochromis niloticus and Grey mullet; Mugil cephalus. Six earthen ponds ( 1 feddan for each) were used in this experiment in three different farms in the same area. Three treatments were tested in two replicates ( 2 ponds), therefore six ponds were stocked with O. niloticus ( $9000 \mathrm{fish} /$ pond) and (3000 fish/pond) of Grey mullet for each pond. O. niloticus and M. cephalus fingerlings averaged 37.18, 38.14 and $36.56 \mathrm{~g}$ for O. niloticus and $23.69,21.89$ and $22.15 \mathrm{~g}$ for M. cephalus in weight were assigned randomly to the three treatments. The first experimental ponds group was supplied by underground water, while the second group was supplied by agricultural drainage water and finally, the third ponds group were irrigated by a mixture between underground water and drainage waste water. The growth experiment period lasted for 26 weeks and the obtained results indicated that, the third ponds group showed the best regarding health and growth of cultured fishes.

Though water performance quality characteristics differ between underground water and agricultural drainage water, but both sources are considered suitable for aquaculture. And ground water and mixture between underground water and drainage water are gave the best of final weights and the highest total yields and quite safe for human consumption.

Keywords: Grey mullet, Mugil cephalus, Nile tilapia, Oreochromis niloticus, aquaculture, growth performance.

\section{INTRODUCTION}

Water is a critical factor in the life of all aquatic species. In aquaculture, any characteristic of water that affects the survival, reproduction, growth, or management of fish or other aquatic creatures in any way is a water quality variable (Boyd, 2003). In all culture systems, fish performs its physiological activities such as breathing, excretion of wastes, feeding, maintaining salt balance and reproduction in the water medium. Accordingly, the overall performance of any aquaculture system is partly determined by its water quality (Alam and Al-Hafedh, 2006). Poor water quality stresses and adversely affects fish growth with consequently low production, profit and product quality (Iwama et al., 2000). Production is reduced when the water contains contaminants that can impair development, growth, reproduction or even cause mortality to the cultured species. As a result, fish farmers are obliged to manage water quality so as to provide a relatively stress-free environment that meets the physical, chemical and biological standards for the fishes' normal health and growth performance (Isyiagi et al., 2009 and Manal Elkareem et al., 2014).

Pollution of aquatic environments with heavy metals has seriously increased worldwide attention and under certain environmental conditions fish may concentrate 
large amounts of some metals from the water in their tissues (Mansour and Sidky, 2002). Some metals such as zinc, iron are essential in trace amounts for normal growth and development; however, others such as cadmium, lead and mercury are potentially harmful to most organisms even in very low concentrations. Heavy metals and more specifically mercury have been reported as hazardous environmental pollutants able to accumulate along the aquatic food chain with severe risk for animal and human health. However, considerable controversy surrounds the interpretation of the relationship between pathological changes in Nile tilapia and grey mullets and prolonged exposure to water pollutants. It was reported that metals are taken up through different organs of the fish and induced morphological, histological and biochemical alterations in the tissues which may critically influence fish quality (Olojo et al., 2005; Fadel \& Gaber, 2007 and Khattaby et al., (2010).

Irrigation of crops with raw, municipal wastewater has been a common practice for many decades in developing countries such as China, Mexico, Peru, Egypt, Lebanon, Morocco, India and Vietnam, mainly due to its nutrient value recognized by farmers (Jiménez et al. 2010). Moreover, in some poor areas of developing countries like Mexico, wastewater reuse represents a critical opportunity of improving living standards by increasing income and ensuring food supplies (Jiménez, 2006). Unfortunately, the use of untreated municipal wastewater in an agricultural setting poses risks to human health due to the potential presence of excreta-related pathogens (viruses, bacteria, protozoan and multicellular parasites), skin irritants and toxic chemicals including heavy metals; although it is uncommon to find unsafe levels of heavy metals in municipal wastewater (Bos et al., 2010). Consequently, it is important to both treat the wastewater and select wastewater treatment processes that reduce pathogen, while retaining nutrients if the water is to be applied for irrigation purposes (Jiménez et al., 2010). Reuse of treated, high-quality reclaimed wastewater for agriculture not only protects human health but is also a good conservation strategy by reducing the consumption of limited drinking water for irrigation and reducing fertilizer costs to the agricultural sector in low-income countries.

The present study was carried out to investigate the effect of using different three water sources (underground water, agricultural drainage water and a mixture of them) in fish farms under the Egyptian conditions on the health and growth performance of cultured Nile tilapia and Grey mullet.

\section{MATERIALS AND METHODS}

The practical part of the present study was carried out in three different private farms in the same area at Tollumbat No. 7 in Riyad City, Kafr El-Sheikh Governorate, Egypt, to evaluate the effect of wastewater in aquaculture. There are two main categories of water supply for aquaculture, groundwater (GW) and agricultural drainage water (ADW). Groundwater (also called well water, or spring water) often differs substantially from surface water in many characteristics such as temperature, turbidity, dissolved gases, $\mathrm{pH}$ and dissolved solids.

The procedures done in this study such as pond preparation, stocking rate and pond daily management are described in details. Also water quality measurements, fish sampling and data collected during harvest are recorded too. Equations and statistical methods for analyzing the specific growth rate, daily weight gain and the condition factor are given. The current experiment was conducted using randomized block design for three treatments of similar surface area $\left(4200 \mathrm{~m}^{2}\right)$ for each pond. 
The experimental ponds were equal in water volume $\left(4200 \mathrm{~m}^{3}\right)$ with the same average water depth of $1,00 \mathrm{~m}$. Each pond had inlet and outlet water gates through which the water level was controlled. The source of underground came from depth of $140 \mathrm{~m}$. While agricultural drainage water came from El-Gharbia drainage canal.

\section{Experimental fish:}

The experimental ponds were stocked with fish species; Oreochromis niloticus and Mugil cephalus. O. niloticus fingerlings were stocked at an average initial length of $14.62,14.31$ and $14.20 \mathrm{~cm}$ and an average initial total weight of $37.18,38.14$ and $36.56 \mathrm{~g}$ for the three treatments, respectively. The average initial length of $M$. cephalus fingerlings were $14.99,13.90$ and $14.28 \mathrm{~cm}$ and an average initial total weight of $23.69,21.89$ and $22.15 \mathrm{~g}$ for the three treatments. The fingerlings of $O$. niloticus and M. cephalus were collected from different fish farms Riyad City, Kafer El-Shiek Governorate. Each pond was stocked with 12000 fish/feddan (9000 O. niloticus and 3000 M.cephalus). The trial lasted for about 168 days started on the $19^{\text {th }}$ of June and harvested on $26^{\text {th }}$ of November 2014.

\section{Treatments:}

O. niloticus and $M$. cephalus were exposed to three treatments, in the first treatment the source of irrigation was from wells, in the second treatment was agricultural drainage water and in the third treatment used was a mixture between underground water and drainage water.

\section{Pond management}

\section{Fertilizers applications}

The experimental ponds were fertilized throughout experimental period (26 weeks) according to Diana and Lin (1998). Fertilization occurred once a week by broadcasting of:

-Organic fertilizer (poultry manure $65 \mathrm{~kg} /$ feddan/week)

-Inorganic fertilizers (Triple super phosphate; $20 \% \mathrm{P}_{2} \mathrm{O}_{5}$ and urea containing $46 \%$ nitrogen) were added as sources of phosphorus and nitrogen to ponds weekly at a rate of $8 \mathrm{~kg} /$ feddan of Triple super-phosphate, by dissolving it in water and splashed all over the experimental ponds water, while $2 \mathrm{~kg}$ urea /feddan were broadcasted at pond water surface.

\section{Supplementary feed}

Commercial diet was manufactured by local animal feed factory. The fingerlings were fed on the commercial floating diet six days/week at a daily feeding rate of $3 \%$ of the estimated fish-weight twice daily at $9.00 \mathrm{am}$ and $3.00 \mathrm{pm}$ during the experimental period.

Feed quantity was adjusted according to average body weight of the biweekly sample of each pond. In order to determine the average weight of fish, biweekly samples were taken by seining where 30 fishes/species from each pond were collected and then reterned again in the pond after individual measuring the weight and length (Jauncey and Rose,1982).

\section{Water management}

Water temperature, dissolved oxygen and $\mathrm{pH}$ were measured weekly at 6 am. and $12 \mathrm{pm}$. using thermometer, dissolved oxygen meter (YSI model 57) and $\mathrm{pH}$ meter (model Corning 345), respectively. Determinations of the other water quality parameters (alkalinity and ammonia) were carried out every two weeks according to the methods of Boyd (1979).

Six fish randomly were taken from treatments, and exposed to LC50 of zinc (18.62 $\mathrm{mg} / \mathrm{l})$, copper $(0.56 \mathrm{mg} / \mathrm{l})$ and cadmium $(11.8 \mathrm{mg} / \mathrm{l})$ separately for the estimation of $\mathrm{Cd}, \mathrm{Cu}$ and $\mathrm{Zn}$ in the musculature and blood. Tissues and blood were 
pooled separately in petri dishes and dried at $60^{\circ} \mathrm{C}$, until the weight became constant. One gram of each tissue from control and exposed groups were transferred to a 100 $\mathrm{ml}$ beaker and $1 \mathrm{ml} \mathrm{H}_{2} \mathrm{SO}_{4}, 2 \mathrm{ml} \mathrm{HNO}_{3}$ and $0.5 \mathrm{ml}$ of perchloric acid was added (Topping, 1973). The beaker was gently heated on a hot plate, until the tissue dissolved. The content of the beaker was diluted to $10-15 \mathrm{ml}$ with triple distilled water. The concentrations of the heavy metals were estimated by Atomic Absorption Spectrophotometer with air-acetylene mixture as fuel.

\section{Fish samples and measurements}

Random samples 30 fish from each species of each pond (two replicate for each treatment) were taken every 2 weeks during the experimental period. During this experiment, body measurements (body weight in $\mathrm{g}$ and body length in $\mathrm{cm}$ ) at biweekly interval throughout the whole experiment period were recorded.

Condition factor was determined by using the following formula:

$$
\mathbf{K} \%=\left[\text { weight }(\mathrm{g}) / \text { length }(\mathrm{cm})^{3}\right] \times 100
$$

Specific growth rate was calculated according to Jauncey and Rose (1982) by using the following formula:

$$
\mathbf{S G R} \%=\frac{\mathrm{LnW} 2-\mathrm{LnW} 1}{\mathrm{t}} \times 100
$$

\section{Clinical examination:}

Samples of the collected fishes were examined using the methods described by Noga (1996) to investigate any lesions on the external body surface.

\section{Postmortem examination:}

The postmortem examination was performed to examine internal organs of fishes according to Stoskopf (1993). The abdominal wall was removed and the internal organs were examined for abnormalities.

\section{Clinical examination:}

Five of the collected fishes were examined using the methods described by Conoary and Hermann (1981) to investigate any lesions on the external body surface. Fishes were examined for skin darkening, discoloration, paleness, congestion, hemorrhages, erosions or ulcers and presence of eye cloudiness, ragged, torn fins or raised scales. Internally, the abdomen was examined for enlargement; distention, parasitic larvae or sunken eyes. Mouth and gills were examined for abnormalities.

\section{Postmortem examination:}

The postmortem examination was performed to examine internal organs of fishes according to Stoskopf, (1993). The abdominal wall was removed and the internal organs were examined macro and microscopically for abnormalities, gills muscles and internal organs were examined for the presence of any visible cysts.

\section{Harvesting}

At the end of the experiment ( $26^{\text {th }}$ of November, 2014), ponds were gradually drained from the water and fish were harvested by seining and transferred to fiberglass tanks and carried to the processing centre where they washed, and the fish of the different fish species were sorted and collectively weighed.

\section{Statistical analysis}

The statistical analysis of data collected was carried out by applying the computer program (SAS, 1996). Differences among means were tested for significance according to Duncan's multiple range test (1955). 


\section{RESULTS AND DISCUSSION}

\section{Physico-chemical water quality results and heavy metals:}

In fish ponds the physico-chemical characteristics of water and flora as primary production and nutritive fauna as secondary productive are well known in their relationship to fish production. These characteristics vary according to certain conditions prevailing such ponds, which depend largely on the nature of soil and water. Furthermore, these properties might vary from a pond to another within the same farm, even if they have the same surface area and the water column as well. These variations are mostly due to the management technique, feeding and fertilization regimes, aeration, fish species and number of stock (Abdel-Hakim et al., 2000).

Table 1: Some water quality parameters and concentrations of heavy metals indifferent farms during the experimental period.

\begin{tabular}{|l|c|c|c|c|}
\hline \multicolumn{1}{|c|}{ Parameters } & No. & UGW & ADW & MW \\
\hline Temp.(C ( $^{\circ}$ & 3 & $24.22 \pm 0.08 \mathrm{c}$ & $27.94 \pm 0.08 \mathrm{a}$ & $25.98 \pm 0.08 \mathrm{~b}$ \\
\hline DO oxygen & 3 & $3.62 \pm 0.009 \mathrm{c}$ & $4.83 \pm 0.009 \mathrm{a}$ & $4.12 \pm 0.009 \mathrm{~b}$ \\
\hline pH & 3 & $7.09 \pm 0.01 \mathrm{c}$ & $8.15 \pm 0.01 \mathrm{a}$ & $7.44 \pm 0.01 \mathrm{~b}$ \\
\hline salinity(mg/l) & 3 & $1.81 \pm 0.007 \mathrm{c}$ & $2.49 \pm 0.007 \mathrm{a}$ & $1.99 \pm 0.007 \mathrm{~b}$ \\
\hline No $_{\mathbf{3}} \mathbf{~ m g / l ~}$ & 3 & $0.00 \pm 0.004 \mathrm{c}$ & $0.72 \pm 0.004 \mathrm{a}$ & $0.31 \pm 0.004 \mathrm{~b}$ \\
\hline NH $_{\mathbf{2}} \mathbf{~ m g / l}$ & 3 & $0.00 \pm 0.004 \mathrm{c}$ & $0.71 \pm 0.004 \mathrm{a}$ & $0.30 \pm 0.004 \mathrm{~b}$ \\
\hline NH $_{\mathbf{3}} \mathbf{~ m g / l}$ & 3 & $0.00 \pm 0.004 \mathrm{c}$ & $0.041 \pm 0.004 \mathrm{a}$ & $0.017 \pm 0.004$ \\
\hline Total hardness(mg/l) & 3 & $955.0 \pm 3.17 \mathrm{c}$ & $1912.0 \pm 3.17 \mathrm{a}$ & $1333.0 \pm 3.17 \mathrm{~b}$ \\
\hline Secchi disck(cm) & 3 & $49.48 \pm 0.76 \mathrm{a}$ & $20.05 \pm 0.76 \mathrm{c}$ & $25.71 \pm 0.76 \mathrm{~b}$ \\
\hline Cu ppm & 3 & $0.02 \pm 0.006 \mathrm{c}$ & $0.05 \pm 0.006 \mathrm{a}$ & $0.04 \pm 0.006 \mathrm{~b}$ \\
\hline Cd ppm & 3 & $0.00 \pm 0.004 \mathrm{c}$ & $0.01 \pm 0.004 \mathrm{a}$ & $0.01 \pm 0.004 \mathrm{~b}$ \\
\hline Pb ppm & 3 & $0.01 \pm 0.006 \mathrm{c}$ & $0.09 \pm 0.006 \mathrm{a}$ & $0.07 \pm 0.006 \mathrm{~b}$ \\
\hline Fe ppm & 3 & $0.29 \pm 0.005 \mathrm{c}$ & $1.15 \pm 0.005 \mathrm{a}$ & $0.43 \pm 0.005 \mathrm{~b}$ \\
\hline Mn ppm & 3 & $0.12 \pm 0.005 \mathrm{c}$ & $0.80 \pm 0.005 \mathrm{a}$ & $0.19 \pm 0.005 \mathrm{~b}$ \\
\hline ZN ppm & 3 & $0.03 \pm 0.006 \mathrm{c}$ & $0.08 \pm 0.006 \mathrm{a}$ & $0.04 \pm 0.006 \mathrm{~b}$ \\
\hline
\end{tabular}

$\mathrm{a}, \mathrm{b}, \mathrm{c} \pm$ Means with the same letter in each column are not significantly different $(\mathrm{P} \geq 0.05)$.

Results obtained in the present study are summarized in Table (1). In general, averages of water temperature ranges were optimal for growth of Nile tilapia and grey mullet, in one way or another close to the records of Lai and Lam (1997). Dissolved oxygen readings were within the normal tolerance level of tilapia (AIT 1986). The $\mathrm{pH}$ values and the average values of seechi disk readings were compatable with the recomendations of Boyd (1998). The average concentration of unionized ammonia $\left(\mathrm{NH}_{3}\right)$ was wihin larable values of tilapia (Diana and Lin, 1998). While the concentration of nitrite seemed to be constant among treatments and came near the records of Diana and Lin (1998) and Ayas et al. (2012). The values of the total alkalinity were compatable to those mentioned by Reddy and DeLaune (2008). The above results showed that all parameters of water quality were within suitable ranges as recommonded by Boyd, (1979). In this respect Khattaby et al. (2010) found that, the highest measurements of dissolved Oxygen, phosphorus and total ammonia were recorded in ponds received agricultural drainage water compared to both irrigation or fertilized water.

The minimum, maximum and mean concentrations of heavy metals in water collected from the three different farms at the Riyad City are summarized in Table 1. The order of the metal concentrations found in water was $\mathrm{Cu}<\mathrm{Zn}<\mathrm{Pb}<\mathrm{cd}<\mathrm{Fe}$. The minimum and maximum copper concentrations varied from 0.02 to $0.05 \mu \mathrm{g} g-1$ wet weight (ww) in the different water sources. The ranges of cadmium were optimal for 
growth of Nile tilapia and grey mullet ww in the different water sources. The minimum and maximum lead concentrations varied from 0.01 to $0.09 \mu \mathrm{g}$ g- 1 wet weight (ww) in the different water sources. The concentrations of iron varied from 0.29 to $1.15 \mu \mathrm{g}$ g- 1 wet weight (ww) in the different water sources, the minimum and maximum nickel concentrations varied from 0.12 to $0.80 \mu \mathrm{g} g-1$ wet weight (ww) in the different water sources and the concentrations of zinc varied from 0.03 to $0.08 \mu \mathrm{g}$ g-1 wet weight (ww) in the different water sources. The differences were significant $(p<0.05)$ in heavy metals concentrations regarding water sources (Table 1) with the highest level at treatment 2 for all.

\section{Heavy metals results:}

Heavy metals concentrations in blood:

As shown in Table (2) the agriculture drainage water (ADW) recorded significantly increased levels of Iron, copper, manganese, cadmium, lead and zinc compared with the underground water (UGW) and mixed water (MW) in the blood of Nile tilapia and grey mullet.

Irrespective of whether the metal is essential or non essential, the accumulation levels of all the three metals in the different organs were significantly high. Metal uptake by aquatic organism is a two phased process, which involves initial rapid adsorption or binding to surface, followed by a slower transport into the cell interior. In epithelial tissues the last step is rate limiting factor in transepithelial movement of metals. Transport of metal into the intracellular compartment may be facilitated by either diffusion of the metal across the cell membrane or by active transport by a carrier protein (Brezonik et al., 1991). A third process involved in determining metal uptake is the speciation of the metals in the medium before contact with gill epithelia. It is generally accepted that metal accumulation in tissues of aquatic animals is dependent upon the exposure concentration and period, as well as some other factors, such as salinity, temperature, interacting agents and metabolic activities of tissue concerned (Mansour and Sidky, 2002 \& Mansour and Sidky, 2002).

Table 2: Concentrations of heavy metals (Fe, $\mathrm{Cu}, \mathrm{Ni}, \mathrm{Cd}, \mathrm{Pb}$ and $\mathrm{Zn}$ ) in blood of $O$. niloticus and $M$. cephalus reared in ponds irrigated with different water sources.

\begin{tabular}{|c|c|c|c|c|c|c|c|}
\hline \multirow[b]{2}{*}{ Parameter } & \multirow[t]{2}{*}{ No. } & \multicolumn{3}{|c|}{ Nile tilapia (ppm) } & \multicolumn{3}{|c|}{ (Aley mullet (ppm) } \\
\hline & & UGW & ADW & MW & UGW & ADW & MW \\
\hline $\mathbf{F e}$ & 3 & $20.64 \pm 0.006 \mathrm{c}$ & $28.79 \pm 0.006 \mathrm{a}$ & $24.67 \pm 0.006 \mathrm{~b}$ & $19.53 \pm 0.006 \mathrm{c}$ & $27.69 \pm 0.006 \mathrm{a}$ & $23.49 \pm 0.006 \mathrm{~b}$ \\
\hline $\mathbf{C u}$ & 3 & $0.11 \pm 0.006 \mathrm{c}$ & $0.33 \pm 0.006 \mathrm{a}$ & $0.52 \pm 0.006 \mathrm{~b}$ & $0.11 \pm 0.006 \mathrm{c}$ & $0.50 \pm 0.006 \mathrm{a}$ & $0.32 \pm 0.006 \mathrm{~b}$ \\
\hline Mn & 3 & $0.31 \pm 0.006 \mathrm{c}$ & $0.88 \pm 0.006 \mathrm{a}$ & $0.49 \pm 0.006 \mathrm{~b}$ & $0.28 \pm 0.006 \mathrm{c}$ & $0.85 \pm 0.006 \mathrm{a}$ & $0.46 \pm 0.006 \mathrm{~b}$ \\
\hline $\mathrm{Cd}$ & 3 & $0.019 \pm 0.006 \mathrm{c}$ & $0.026 \pm 0.006 \mathrm{a}$ & $0.020 \pm 0.006 \mathrm{~b}$ & $0.018 \pm 0.006 \mathrm{c}$ & $0.027 \pm 0.006 \mathrm{a}$ & $0.019 \pm 0.006 \mathrm{~b}$ \\
\hline $\mathbf{P b}$ & 3 & $5.08 \pm 0.006 \mathrm{c}$ & $7.52 \pm 0.006 a$ & $6.61 \pm 0.006 \mathrm{~b}$ & $4.57 \pm 0.006 \mathrm{c}$ & $7.06 \pm 0.006 a$ & $6.12 \pm 0.006 \mathrm{~b}$ \\
\hline$\overline{\mathbf{Z N}}$ & 3 & $19.56 \pm 0.006 \mathrm{c}$ & $31.48 \pm 0.006 \mathrm{a}$ & $22.65 \pm 0.006 \mathrm{~b}$ & $17.42 \pm 0.006 \mathrm{c}$ & $29.34 \pm 0.006 \mathrm{a}$ & $20.51 \pm 0.006 \mathrm{~b}$ \\
\hline
\end{tabular}

$\mathrm{a}, \mathrm{b}, \mathrm{c} \pm$ Means with the same letter in each column are not significantly different $(\mathrm{P} \geq 0.05)$.

\section{Heavy metals concentrations in the Musculatures of fish:}

Obtained results in the present study show that, the metal concentrations in fish musculature of $O$. niloticus and $M$. Cephalus are closely associated with metal content of water in the three treatments (Table 3) and detected in the following order: $\mathrm{Fe}>\mathrm{Cu}$ $>\mathrm{Mn}>\mathrm{Cd}>\mathrm{Pb}>\mathrm{Zn}$. This may be attributed to the abundance of these metals in water and sediments by the same pattern. A remarkable relationship between heavy metals concentrations in musculature and source of water were observed by Ibrahim et al. (2000 a) and Ibrahim and El-Naggar (2006). The present results indicate that the concentrations of heavy metals in fish musculature reared in ADW are higher than those of underground water and the mixture between them (Table 3). 
Table 3: Concentrations of heavy metals (Fe, $\mathrm{Cu}, \mathrm{Ni}, \mathrm{Cd}, \mathrm{Pb}$ and $\mathrm{Zn}$ ) in musculatures of O. Niloticus and $M$. cephalus reared in ponds irrigated with different water sources.

\begin{tabular}{|l|c|c|c|c|c|c|c|}
\hline Parameter & \multirow{2}{*}{ No. } & \multicolumn{3}{|c|}{ Nile tilapia } & \multicolumn{3}{c|}{ Grey mullet } \\
\cline { 2 - 7 } & & UGW & ADW & MW & UGW & ADW & MW \\
\hline Fe ppm & $\mathbf{3}$ & $42.70 \pm 0.006 \mathrm{a}$ & $62.38 \pm 0.006 \mathrm{c}$ & $46.91 \pm 0.006 \mathrm{~b}$ & $39.47 \pm 0.008 \mathrm{a}$ & $56.31 \pm 0.008 \mathrm{c}$ & $42.32 \pm 0.008 \mathrm{~b}$ \\
\hline Cu ppm & $\mathbf{3}$ & $0.29 \pm 0.006 \mathrm{a}$ & $1.19 \pm 0.006 \mathrm{c}$ & $0.67 \pm 0.006 \mathrm{~b}$ & $0.18 \pm 0.005 \mathrm{a}$ & $0.98 \pm 0.005 \mathrm{c}$ & $0.57 \pm 0.005 \mathrm{~b}$ \\
\hline Mn ppm & $\mathbf{3}$ & $0.73 \pm 0.006 \mathrm{a}$ & $1.34 \pm 0.006 \mathrm{c}$ & $0.94 \pm 0.006 \mathrm{~b}$ & $0.52 \pm 0.006 \mathrm{a}$ & $01.13 \pm 0.006 \mathrm{c}$ & $0.75 \pm 0.006 \mathrm{~b}$ \\
\hline Cd ppm & $\mathbf{3}$ & $0.024 \pm 0.006 \mathrm{a}$ & $0.032 \pm 0.006 \mathrm{c}$ & $0.024 \pm 0.006 \mathrm{~b}$ & $0.022 \pm 0.006 \mathrm{a}$ & $0.031 \pm 0.006 \mathrm{c}$ & $0.025 \pm 0.006 \mathrm{~b}$ \\
\hline Pb ppm & $\mathbf{3}$ & $2.19 \pm 0.006 \mathrm{a}$ & $3.28 \pm 0.006 \mathrm{c}$ & $2.55 \pm 0.006 \mathrm{~b}$ & $1.79 \pm 0.006 \mathrm{a}$ & $3.78 \pm 0.006 \mathrm{c}$ & $2.22 \pm 0.006 \mathrm{~b}$ \\
\hline ZN ppm & $\mathbf{3}$ & $19.97 \pm 0.006 \mathrm{a}$ & $30.12 \pm 0.006 \mathrm{c}$ & $20.20 \pm 0.006 \mathrm{~b}$ & $18.31 \pm 0.006 \mathrm{a}$ & $31.04 \pm 0.006 \mathrm{c}$ & $21.89 \pm 0.006 \mathrm{~b}$ \\
\hline
\end{tabular}

$\mathrm{a}, \mathrm{b}, \mathrm{c} \pm$ Means with the same letter in each column are not significantly different $(\mathrm{P} \geq 0.05)$.

Karakoc and Dincer (2003) reported that $\mathrm{Zn}$ accumulation increased with increasing temperature. Karakoc (1999) observed increase in the uptake of $\mathrm{Cu}$ in the liver, gill and musculature of Tilapia nilotica at low salinities since a decrease in salinity from 20 to 50 per cent caused an increase in the metal uptake. Dallinger and Kautzky (1985) reported the accumulation of class ' $\mathrm{B}$ ' metals in metabolically active organs such as liver and kidney.

\section{Growth parameters:}

Growth and survival which together determine the ultimate yield are influenced by a number of biological parameters such as genetic materials and managerial practices, including water and food quality, energy content of the food and stocking density (El-Sayed 1999 and Ashagrie et al., 2008).

Table 4: The effect of water source on growth parameters of Nile Tilapia and Grey mullet.

\begin{tabular}{|c|c|c|c|c|c|c|c|}
\hline \multirow{2}{*}{ Parameters } & \multirow{2}{*}{ No. } & \multicolumn{3}{|c|}{ Nile tilapia } & \multicolumn{3}{|c|}{ Grey mullet } \\
\hline & & UGW & ADW & MW & UGW & ADW & MW \\
\hline Final weight & 60 & $298.65 \pm 4.98 \mathrm{a}$ & $231.67 \pm 4.98 b$ & $287.43 \pm 4.98 \mathrm{a}$ & $265.61 \pm 5.22 \mathrm{a}$ & $207.22 \pm 5.22 b$ & $247.13 \pm 5.22 \mathrm{a}$ \\
\hline Initial length & 60 & $14.62 \pm 1.01 \mathrm{a}$ & $14.31 \pm 1.01 \mathrm{ab}$ & $14.20 \pm 1.01 \mathrm{~b}$ & $14.99 \pm 0.83 a$ & $13.90 \pm 0.83 \mathrm{c}$ & $14.28 \pm 0.83 b$ \\
\hline Initial K & 60 & $1.19 \pm 0.27 \mathrm{~b}$ & $1.32 \pm 0.27 \mathrm{a}$ & $1.29 \pm 0.27 \mathrm{a}$ & $0.72 \pm 0.14 \mathrm{c}$ & $0.82 \pm 0.14 \mathrm{a}$ & $0.77 \pm 0.14 \mathrm{~b}$ \\
\hline Final $\mathrm{K}$ & 60 & $1.55 \pm 0.29 a$ & $1.72 \pm 0.29 \mathrm{a}$ & $1.61 \pm 0.29 \mathrm{a}$ & $1.00 \pm 0.37 \mathrm{a}$ & $1.07 \pm 0.37 \mathrm{a}$ & $1.05 \pm 0.37 \mathrm{a}$ \\
\hline DWG, g/fish & 60 & $1.56 \pm 0.35 \mathrm{a}$ & $1.15 \pm 0.35 b$ & $1.49 \pm 0.35 \mathrm{ab}$ & $1.73 \pm 0.29 \mathrm{a}$ & $1.32 \pm 0.29 b$ & $1.61 \pm 0.29 \mathrm{a}$ \\
\hline SGR, \%/d & 60 & $1.24 \pm 0.19 \mathrm{a}$ & $1.06 \pm 0.19 b$ & $1.22 \pm 0.19 \mathrm{a}$ & $1.72 \pm 0.26 \mathrm{a}$ & $1.57 \pm 0.26 b$ & $1.72 \pm 0.26 \mathrm{a}$ \\
\hline
\end{tabular}

$\mathrm{a}, \mathrm{b}, \mathrm{c} \pm$ Means with the same letter in each column are not significantly different $(\mathrm{P} \geq 0.05)$.

Table (4) shows the effect of water sources on growth parameters of monosex $O$. niloticus and M. cephalus. As described in Table (4), the initial body weight (37.18, 38.14 and 36.56g) and body length $(14.62,14.31$ and $14.20 \mathrm{~cm})$ for Nile tilapia and initial body weight $(23.69,21.89$ and $22.15 \mathrm{~g})$ and body length (14.99, 13.90 and $14.28 \mathrm{~cm}$ ) for M. Cephalus reared at the beganing of th experiment. The differences in initial $\mathrm{BW}$ and $\mathrm{BL}$ among the different treatments were insignificant indicating the random distribution of fish around the different experimental treatments. At the end of the experimental period the averages of BW were 298.65, 231.67 and $287.43 \mathrm{~g}$ and BL found to be $27.09,24.03$ and $26.68 \mathrm{~cm}$ for Nile tilapia and 265.61, 207.22 and 249.13g and BL found to be 30.31, 26.69 and $28.85 \mathrm{~cm}$ for $M$. cephalus for the three water sources, UGW, ADW and MW, respectively and the differences among treatments were significant $(\mathrm{P}<0.05)$. The obtained results related to the abundance of natural food (phytoplankton and zooplankton) in the experimental 
ponds. These results are in agreement with those of Mc Donald (1985) who found that tilapia fish (O. aureus) fed on blue green algae (Anabaena spp.) gained more weight than the control. Tefei et al. (2000) demonstrated that $O$. niloticus was found to be essentially phytoplanktivorous in Lake Chamo; the blue green algae contributed over $60 \%$ of the total food ingested, of these, and more than $50 \%$ was due to Anabaena. From these data, it can be concluded that fish do not need to be fed immediately after stocking but can be supported by the natural food in the pond ecosystem (Abdelghany et al., 2002; Kamal and Agouz 2006). Nutrient enrichment can enhance primary productivity in aquatic ecosystem (Geiger, 1983). The increase of plankton abundance can significantly increase fish production in ponds (Geiger and Parker, 1985). On the other hand, Khattaby et al., (2010) found that at the end of experimental period, averages of final weights were $223.06,272.79$ and $330.80 \mathrm{~g}$ for $O$. niloticus reared in fresh water, fertilized water and agricultural drainage water, respectively.

Condition factor of fish is essentially a measure of relative muscle to bone growth and the differing growth responses of these tissues to diet treatment may be reflected by changes in condition factor (Ibrahim et al., 2000 b; Soltan et al., 2006). It is frequently assumed to reflect not only characteristics of fish such as health, reproductive state and growth but also characteristics of the environment such as habitat quality, water quality and prey availability (Liao et al. 1995).

As described in Table (4), the averages of initial (K) for Nile tilapia were 1.19, 1.32 and 1.29 and $0.72,0.82$ and 0.77 for M. cephalus. While at the end of this experiment the averages of $(\mathrm{K})$ values were $1.55,1.72$ and 1.61 for Nile tialpia and 1.00, 1.07 and 1.05 for M. Cephalus for the three treatments T1, T2 and T3, respectively. The differences among treatments were significant $(\mathrm{P}<0.05)$. Putheti et al., (2008) found that, $\mathrm{K}$ values in well waters were observed in well highly significant than in drainage water. Concentrations of metals and nonmetals in aquatic environment are known to affect the metabolism of bacteria and higher organisms in the water. The effect of pollution of water on a body can be reduced to that of predicting the dissolve oxygen content (Obire et al., 2008).

Manal Elkareem et al. (2014) found that, the mean condition factor of fish was found to be $1.23 \mathrm{~g} / \mathrm{cm} 3$ and $1.22 \mathrm{~g} / \mathrm{cm}^{3}$ in treated wastewater and White Nile, respectively. Both values were above 1.0 indicating good conditions of the fish (Barnham and Baxter, 1998), however, they were below those obtained by (Nwabueze, 2013) for Clarias anguillaris which may be attributed to the difference in species. Furthermore, King (1995) attributed differences in condition factors of fish to food abundance, adaptation to the environment and gonadal development.

Table (4) shows the effect of the effect of sources of water on daily weight gain (DWG) of $O$. niloticus and grey mullet. As described in this table, the averages of (DWG) for fish reared were 1. 56, 1.15 and $1.49 \mathrm{~g} /$ fish for Nile tilapia and 1.73, 1.32 and 1.61 for $\mathrm{g} /$ fish grey mullet for the three treatments T1, T2 and T3, respectively. Analysis of variance indicated that the studied water sources were significantly affected on DWG of Nile tilapia and grey mullet during the experimental period. Soliman (2006) when practically studied using resirculated ground water for maximum productivity of $O$. niloticus found that, differences were significant between total weight and daily weight gain values for fishes reared in well water over those that cultured in both mixed and recirculated waters under the three stocking density tested. In the same trend, specific growth rate (Table 4), for Nile tilapia were $1.24,1.06$ and $1.22 \% / \mathrm{d}$ and $1.72,1.57$ and $1.72 \%$ /d for grey mullet. Analysis of variance indicated that the studied water sources were significantly affecting the SGR of Nile tilapia and grey mullet during the experimental period. 


\section{Total yield:}

Averages of total yield at the end of the experiment were listed in Table (5). As described in this Table, Oreochromis niloticus gained the highest yield $7023.85 \mathrm{~kg}$ $100 \%$ compared with $1983.82 \mathrm{~kg}-28.24 \%$ gained by grey mullet.

As in this Table, Nile tilapia (T1) gained the highest yield $(2607.21 \mathrm{~kg})$, compared with (T2) (1897.38kg) and (T3) $(2519.26 \mathrm{~kg})$. While total yield of grey mullet, (T1) gained the highest yield $(741.05 \mathrm{~kg})$, compared with (T2) $(553.28 \mathrm{~kg})$ and (T3) $(689.49 \mathrm{~kg})$. These results indicated that, the low of gain in the agriculture drainage water (ADW) compared with underground water (UGW) and mixed water (MW) reported in similar study (Soliman, 2006) when practically studied using of ground water for maximum productivity of $\mathrm{O}$. niloticus found that, total yield for fishes reared in well water and mixed water were increase than those that cultured in recirculated waters under the three stocking density tested. In the same trend.

Table 5: The effect of water source on total yield of Nile Tilapia and Grey mullet.

\begin{tabular}{|c|c|c|c|c|}
\hline \multirow{2}{*}{ Treatments } & \multicolumn{2}{|c|}{ Nile tilapia } & \multicolumn{2}{c|}{ Grey mullet } \\
\cline { 2 - 5 } & Yield (kg/feddan) & \%total yield & Yield (kg/feddan) & \%total yield \\
\hline T1 (UGW) & 2607.21 & $37.12 \%$ & 741.05 & $37.35 \%$ \\
\hline T2 (ADW) & 1897.38 & $27.01 \%$ & 553.28 & $27.89 \%$ \\
\hline T3 (MW) & 2519.26 & $35.87 \%$ & 689.49 & $34.76 \%$ \\
\hline Total yield & 7023.85 & $100 \%$ & 1983.82 & 100 \\
\hline \% of the biggest value & $100 \%$ & & $28.24 \%$ & \\
\hline
\end{tabular}

\section{Chemical composition:}

The changes in chemical composition during development and in response to different factors are the result of differential growth of tissues. The main tissues involved in the whole-body growth are bones, muscles and adipose tissues. The relative development of these tissues is very important for the conformation of fish and thus its yield in processing (Soltan et al., 1999).

Proximate analysis shows significant $(\mathrm{P} \leq 0.001)$ effects in the three treatments. As described in Table (6) underground water released the highest values of protein, while agriculture drainage water released the highest values of fat and ash. This closely met the remarks of Soliman (2006) who emphasized that groundwater is commonly considered the most desirable water source for aquaculture because, at a given site, it is usually consistent in quantity and quality, and free of toxic pollutants.

Table 6: Least-square means and tested standard error of the factors affecting on chemical composition $\%$ DM basis of Nile tilapia and Grey mullet.

\begin{tabular}{|c|c|c|l|l|l|l|}
\hline Species & Treatment & No. & Moisture\% & \multicolumn{1}{|c|}{ Protein\% } & Fat* & Ash\% \\
\hline \multirow{3}{*}{ o. niloticus } & UGW & $\mathbf{6}$ & $62.40 \pm 0.08 \mathrm{a}$ & $61.80 \pm 0.09 \mathrm{a}$ & $20.10 \pm 0.06 \mathrm{c}$ & $18.10 \pm 0.05 \mathrm{~b}$ \\
\cline { 2 - 7 } & ADW & $\mathbf{6}$ & $61.90 \pm 0.08 \mathrm{a}$ & $58.40 \pm 0.09 \mathrm{c}$ & $22.40 \pm 0.06 \mathrm{a}$ & $19.20 \pm 0.05 \mathrm{a}$ \\
\cline { 2 - 7 } & MW & $\mathbf{6}$ & $62.30 \pm 0.08 \mathrm{a}$ & $60.20 \pm 0.09 \mathrm{~b}$ & $21.50 \pm 0.06 \mathrm{~b}$ & $18.30 \pm 0.05 \mathrm{~b}$ \\
\hline \multirow{3}{*}{ M. cephalus } & UGW & $\mathbf{6}$ & $65.90 \pm 0.07 \mathrm{a}$ & $64.40 \pm 0.06 \mathrm{a}$ & $18.20 \pm 0.05 \mathrm{~b}$ & $17.40 \pm 0.06 \mathrm{~b}$ \\
\cline { 2 - 7 } & ADW & $\mathbf{6}$ & $64.20 \pm 0.07 \mathrm{~b}$ & $61.70 \pm 0.06 \mathrm{c}$ & $19.60 \pm 0.05 \mathrm{a}$ & $18.70 \pm 0.06 \mathrm{a}$ \\
\cline { 2 - 7 } & MW & $\mathbf{6}$ & $65.10 \pm 0.07 \mathrm{ab}$ & $63.10 \pm 0.06 \mathrm{~b}$ & $18.70 \pm 0.05 \mathrm{ab}$ & $18.20 \pm 0.06 \mathrm{ab}$ \\
\hline
\end{tabular}

\section{Clinical and Post-mortem Examination of fishes:}

Some tilapia fish from ponds supplied with agriculture drainage water showed skin darkening, exophthalmia, presence of eye cloudiness, abdominal distension with 
watery fluids exuded from the vent as shown in Photo (1). Internally, Liver was pale, enlarged in some fishes and congested with necrotic patches in other fishes. Spleens were congested and enlarged in most examined fishes. Kidneys were congested in some fishes and apparently normal in the others. Gall- bladder was enlarged and engorged with bile in some cases it contain white patches. On the other side, clinical examinations of Grey mullet revealed the presence of excessive mucus secretion covering the skin and dark grey coloration or even blackness of the skin. Hemorrhagic spots over the skin were occasionally seen and the eyes appeared cloudy. In addition to that there were easily detached scales with skin ulceration (Photo 2). Such signs were closely matching the findings of Eaton and Stinson (1983) and Fernandes and Mazon (2003).Concerning the damaged internal organs Huang et al. (2006) attributed that to the pollution by residues of agriculture and industrial activities in ponds supplied with agriculture waste water.

\section{CONCLUSION}

In spite of the differences in most water physicochemical characteristics between underground and fresh water, these characteristics still in adequate range which could be considered most suitable for aquaculture purposes. Concerning heavy metals residues, their levels in the edible muscles of the investigated fish species reared in either underground or fresh water are quite safe for human consumption, where these residues were below the permissible concentrations mentioned by national organizations interested in pollution and human health. According to the obtained results as we recommended to use mixed water of underground and agriculture drainage water as reliable water sources for fish rearing ponds which gave the of best final weights and the highest total yields.

\section{REFERENCES}

Abdelghany, A. E.; Ayyat, M. S. and Ahmed, M. H. (2002): Appropriate timing of supplemental feeding for production of Nile tilapia, silver carp, and common carp in fertilized polyculture ponds. J. World Aquacult. Soci., 33 (3): 307-315.

Abdel-Hakim, N. F.; Bakeer, M. N. and Soltan, M. A. (2000): Effect of two manuring systems on water quality and plankton communities in fish ponds. Conference of Social and Agricultural Development of Sinai, El-Arish-North Sinai, 16-19 May, Egypt, pp. 147-158.

Alam, A and Al-Hafedh, Y. (2006). Diurnal dynamics of water quality parameters in an aquaculture system based on recirculating green water technology. J. Appl. Sci. Environ. Manag., 10:19-21.

AIT. Asian Institute of Technology (1986). Buffalo/ fish and duck/fish integrated systems for small - scale farmers at the family level. AIT Research Report No. 198. Bangkok, Thailand, $138 \mathrm{pp}$.

Ashagrie G, Abebe, G., Seyoum, M. (2008). Effect of stocking density on the growth performance and yield of Nile tilapia (Oreochromis niloticus L., 1758) in a cage culture system in Lake Kuriftu, Ethiopia. Aquacult. Res., 39:1450-1460.

Authman, M. M. N.; Abbas, W. T. and Gaafar, A. Y. (2013). Metals concentrations in Nile tilapia Oreochromis niloticus (Linnaeus, 1758) from illegal fish farm in AlMinufiya Province, Egypt, and their effects on some tissues structures. Ecotoxicol. Environ. Saf., 84: 163-172. 
Ayas, S.C.; Aktas, Ô.; Findik, N.; Akca, L.; Kinaci, C. (2013). Effect of recirculation on nitrogen removal in a hybrid constructed wetland system. Ecol. Eng., 40:1-5.

Brezonik, P. L.; King, S. O. and Mach, C. E. (1991). The influence of water chemistryon trace metal bioavailability and toxicity to aquatic organisms. In: Metal ecotoxicology concepts and applications (Eds: M.C.Newman and A.W. Mdntosh). Lewis Publishers Inc., Michigan. pp. 1-26.

Boyed, C. E. (1998). Water quality for pond aquaculture. Research and development series No. 43. pp. 37. International Centre for aquaculture and aquatic Environments. Alabama Agricultural Experiment Station. Auburn University.

Bos, R.; Carr, R. and Keraita, B. (2010). Assessing and mitigating wastewater-related health risks in low-income countries: An introduction. In wastewater irrigation and health. Assessing and Mitigating Risk in Low-Income Countries; Drechsel, P., Scott, C.A., Raschid-Sally, L, Redwood, M., Bahri, A., Eds.; International Water Management Institute and International Development Research Centre (IDRC): London, UK, pp. 29-47.

Barnham, C. and Baxter, A. (1998). Condition Factor, K, for Salmonid Fish. Fisheries Notes. State of Victoria, Department of Primary Industries 2003:3 pp.

Boyd, C. E. (1979). Water Quality in Warm Water Fish Ponds. Ed Claude E. Boyd. Third printing, 1984. Pub. Auburn Univ., Agri.Exp. Station, AID/Dsan- G.G.00 39. $359 \mathrm{pp}$.

Boyd, C. E. (2003). Guidelines for aquaculture effluent management at the farm-level. Aquacult., 226:101-112.

Diana, J. S. and Lin, C. K. (1998). The effects of fertilization and water management on growth and production of Nile tilapia in deep ponds during the dry season. J. World Aquacult. Soci., 29 (4): 405 - 413.

Dallinger, R. and Kautzky, H. (1985). The importance of contaminated food for the uptake of heavy metals by rainbow trout (Salmo gairdneri) a field study. Oceologia, 67: 82-89.

Duncan, D.B. (1955). Multiple range and multiple F test. Biometrics, 11:1-42.

Eaton, D. L and Stinson, M. D. (1983): Concentration of lead, cadmium, mercury and copper in the cray fish (Pacifasticu sleniusculus) obtained from a lake receiving urban runoff. Arch. Environ. Contam. Toxicol., 12: 693- 700.

El-Sayed, A. F. (1999). Alternative dietary protein sources for farmed tilapia, Oreochromis pp. Aquaculture 179:149-168.

Fadel, N. G. and Gaber, H. S. (2007). Effect of exposure to pollutants on different organs of two fish species in Rossetta branch at River Nile. Egypt. J. Comp. Path. and Clinic. Path., 20(1): 364-89.

Fernandes, M. N. and Mazon, A. F. (2003). Environmental pollution and fish gill morphology, pp. 203-231. In: Fish Adapttions. (Val AL, Kapoor BG eds.). Sci. Pub. Enfield, USA.

Geiger, J. G (1983): A review of pond zooplankton production and fertilization for the culture of larval and fingerling striped bass. Aquacult., 35:353-369.

Geiger, J. G. and Parker, N. C. (1985): Survey of striped bass hatchery management in the southeastern United States. Prog. Fish- cult. 47: 1-13

Huang, X.; Choi, Y.; Im, H.; Yarimaga, O.; Yoon, E. and Kim, H. (2006). Aspartate aminotransferase (AST/GOT) and alanin aminotransferase (ALT/GPT) detection techniques. Sesors 6: 756-782.

Ibrahim, N. A. and El-Naggar, G. O. (2006). Assessment of heavy metals levels in water, sediment and fish at cage fish culture at Damietta Branch of the river Nile. J. Egypt. Acad. Environ. Develop., 7 (1): 93-1114. 
Ibrahim, A. M.; Bahnasawy, M. H.; E.Mansy, S. and El-Fayomy, R. I. (2000 a). On some heavy metal levels in water, sediment and marine organisms from the Mediterranean coast of Lake Manzalah. Egypt. J. Aqua. Biol. Fish., 4(4): 61-81.

Ibrahim, M. K.; Fatma, A. Hafez and Soltan, M. A. (2000 b): Effect of organic fertilization, supplementary feeding and stocking rate on growth performance of Nile tilapia and silver carp. Egypt. J. Agric., Res., 78 (4):1775-1799.

Isyiagi, N.; Veverica, K.; Asiimwe, R. and Daniels, W., (2009). Manual for commercial pond production of the African catfish in Uganda, Kampala, $222 \mathrm{pp}$.

Iwama, G.; Vijayan, M. and Morgan, J. (2000). The stress response in fish. Ichthyology, recent research advances. Oxford and IBH Publishing Co, Pvt. Ltd, New Delhi.

Jauncey, K. and Rose, B. (1982). A guide to tilapia feeds and feeding. Institute of Aquaculture, University of Sterling, Scotland.

Jiménez, B. (2006). Irrigation in developing countries using wastewater. Int. Rev. Environ. Strateg. 2: 229-250.

Jiménez, B.; Mara, D.; Carr, R. and Brissaud, F. (2010). Wastewater treatment for pathogen removal and nutrient conservation: Suitable systems for use in developing countries. In Wastewater Irrigation and Health. Assessing and Mitigating Risk in Low-Income Countries; Drechsel, P., Scott, C.A., RaschidSally, L., Redwood, M., Bahri, A., Eds.; International Water Management Institute and International Development Research Centre (IDRC): London, UK, 149-169 pp.

Kamal, S. M. and Agouz, H. M. (2006): Production of Nile Tilapia (Oreochromis niloticus) and silver carp (Hypophthalmicthys molitrix val.) in earthen ponds fertilized by blue green algae and poultry manure. Mnsoura University Journal of Agricultural Sciences vol. 31 (6): 3389- 3398.

Karakoc, M. (1999). Effects of salinity on accumulation of copper in liver, gill and musculature tissue of Tilapia nilotica. Tr. J. Zool., 23: 299-303.

Karakoc, M. and Dincer, S. (2003). Effect of temperature on zinc accumulation in the gill, liver and kidney of Oreochromis niloticus. Bull. Environ. Contam. Toxicol., 71: 1077-1083.

Khattaby, A. A.; Fayza E. Abbas; Soltan, M. A. and El-Sayaad, G. A. (2010): Effect of using different water sources on the growth performance of mono sexed Nile tilapia (Oreochromis niloticus) reared in earthen ponds. Abbassa Int. J. Aqua. Special Issue (The Third Scientific Conference Al Azhar University, Cairo 1718 October 2010. 129-142 pp.

King, M. (1995). Fisheries Biology, Assessment and Management. Fishing News Books, Oxford, UK.

Lai, P.C.C. and Lam, P.K.S. (1997). Major pathways for nitrogen removal in wastewater stabilization ponds. Water Air Soil Poll. 94, 125-136.

Liao, H.; Pierce, C. L.; Wahl, D. H.; Rasmussen, J. B. and Leggett, W. C. (1995): Relative weight (WR) as field assessment tool: relationships with growth, prey biomass, and environmental condition: Trans Amer. Fish Soc., 124: 387-400.

Manal, M. A. Elkareem; Abeer, A. M. H. and Abdel Karim, S. A. (2014). Relationship of Biometric Size-Weight, Nutritive Value, and Metal Concentrations in Clariaslazera (Cuvier and Valenciennes) Reared in Treated Wastewater. Jordan J. Biolog. Scie. 7(3): 217- 225. 
Mansour, S. A. and Sidky, M. M. (2002). Ecotoxicological studies: 3. Heavy metals contaminating water and fish from Fayoum Gov., Egypt. Food Chemistry, 78: $15-22$.

Mason, C. F. (1991). Biology of Fresh Water Pollution. Longman Singapore publishers, Singapore.

Mc Donald, M. E. (1985): Carbon budgets for a phytoplanktivorours fish fed three different unialgal populations, Oecologia (Berlin). 67: 246-249.

Nwabueze, A. A. (2013). Growth performance of the mudfish, Clarias anguillaris (Pellegrin, 1923) in Treated and Untreated Domestic Sewage. Sustainable Agricult. Res., 2 (1): 62-69.

Obire, O.; Ogan, A. and Okigbo, R. (2008). Impact of fertilizer plant effluent on water quality. Int. J. Envir. Sci. Tech. (Iran). 5 (1): 107-118.

Olojo, E. A.; Olurin, K. B.; Mbaka, G. and Oluwemim, A. D. (2005). Histopathology of the gills and liver tissues of the African catfish (Clarias gariepinus) exposed to lead. African J. of Biochemistry, 4 (1) 117 - 22.

Putheti, R. R.; Okigbo, R. N.; Madhusoodan S. A. and Radha, L. (2008). Ground water pollution due to aquaculture in east coast region of Nellore district, And hrapradesh, India. African J. of Environ. Sci. and Tech. Vol. 2 (3): 046-050 pp.

Reddy, K. R. and DeLaune, R. D. (2008). Biogeochemistry of Wetlands: Science and Applications; CRC Press, Taylor \& Francis Group: Boca Raton, FL, USA.

Noga E. J. (1996). Fish Disease: diagnosis and treatment .Moshy-Year book, Inc, Naples, Tokyo, New York 294 pp..

Shoko, A. P. A.; Matola, H.; Mzighani, S. and Mahika, G. (2011). Fishpond performance of Nile tilapia Oreochromis niloticus (Linnaeus, 1758) in the Lake Victoria basin, Tanzania. J Aquac. Trop., 26:17-28.

Soliman, M. M. A. (2006). Practical studies on the using of resirculated ground water for maximum productivity of Oreochromis niloticus.Ph.D. Thesis, Fac. of Sci., Zag. Univ.

Soltan, M. A.; Abdel-Hakim, N. F. and Bakeer, M. N. (1999): Effect of stocking rate, organic fertilization and supplementary feed on growth performance, carcass and chemical analysis of Nile tilapia, Oreochromis niloticus. Egyptian J. Nutrition and Feeds 2 (Special Issue): 765-778.

Soltan, M. A.; Bakeer, M. N. and Samra, I. M. (2006): Effect of some feeding regimes on water quality, growth and productivity of Nile tilapia, Oreochromis niloticus reared in earthen ponds. Egypt. J. Agric. Res., 84(1A):1-18 (Special Issue for the first Scientific Conference on Modern Attitudes in Aquaculture), Sharm El-Sheikh, 13-15 December, 2006.

Stoskopf, M. K. (1993). Fish medicine. W. B. Saunders Co. Philadelphia, Pennsylvania, 19106, USA.

Tefei, Y., Admassu, D. and Mengistou, S. (2000): The food and feeding habit of Oreochromis niloticus L. (Pisces: Cichlidae) in lake Chamo, Ethiopia. Sinet, an Ethiopian J. of Sci., 23: (1): 1-12.

Topping, G. (1973). Heavy metals from Scottish water. Aquacult., 1: 379-384. 


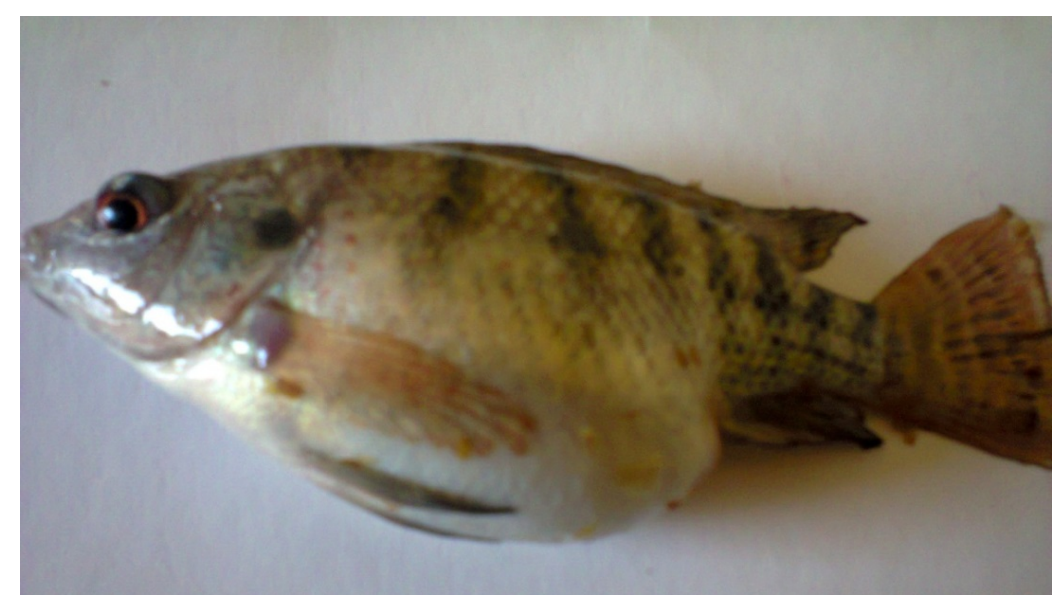

Photo 1: Tilapia showing skin darkening, exophthalmia, presence of eye cloudiness and abdominal distension:

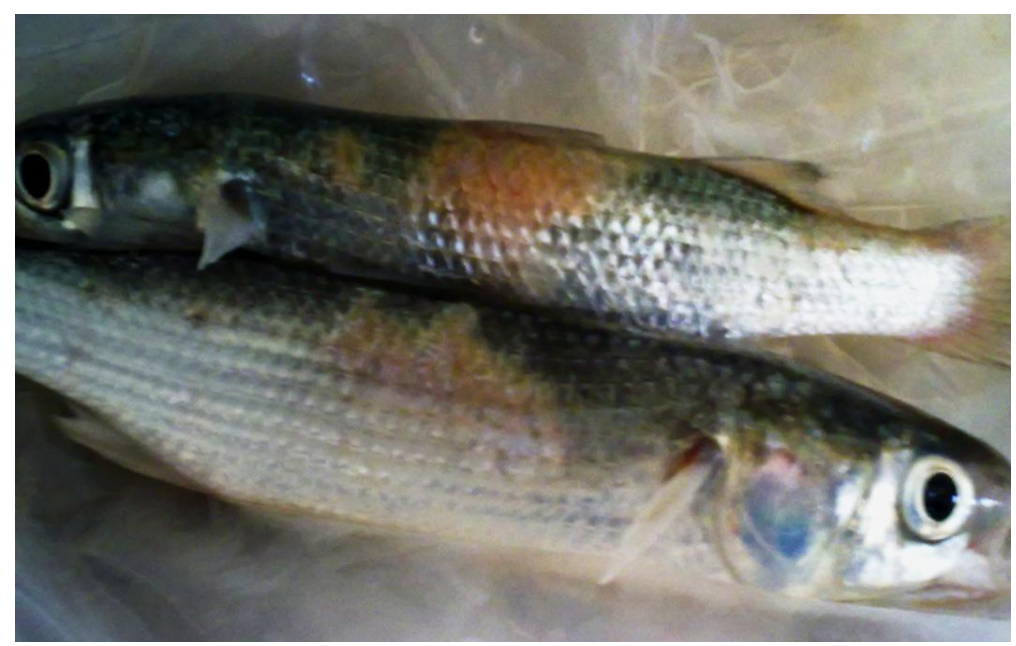

Photo 2: Grey mullet showing darkness in the color of the skin, detachment of the scales, large irregular hemorrhages on the body surface. 


\section{ARABIC SUMMARY}

تأثير بعض مصادر مياه الإستزراع السمكى على أداء النمو لأسماك البلطي النيلي والبورى

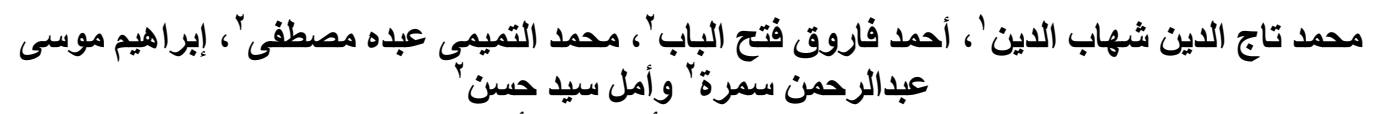

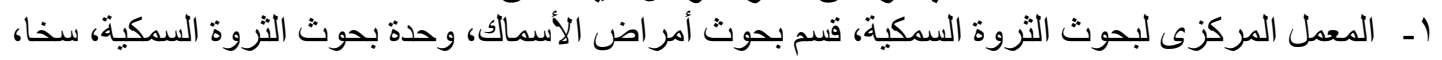

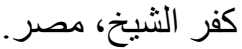

r-ـ المعمل المركزى لبحوث الثروة السمكية، قسم بحوث الانتاج ونظم الاستزر اع السمكى، مصر.

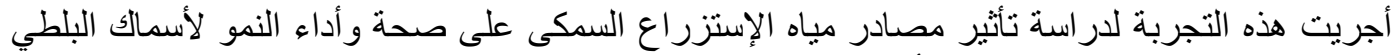

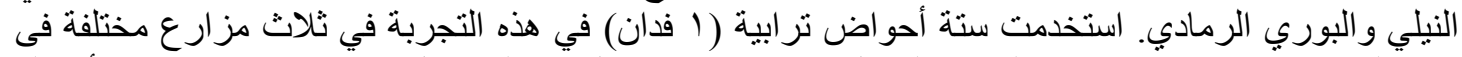

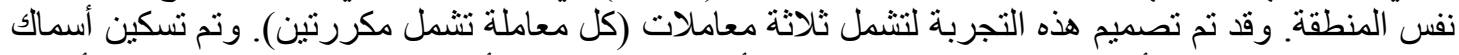

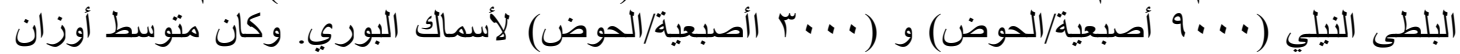

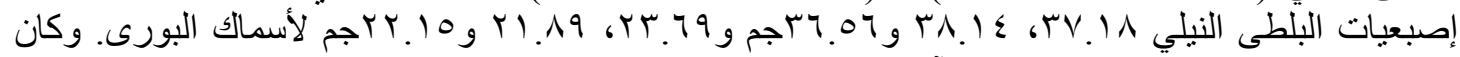

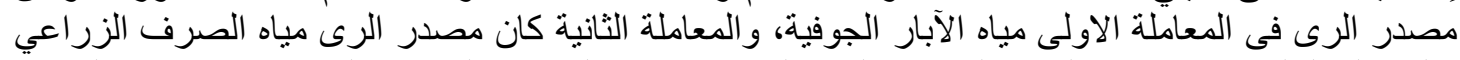

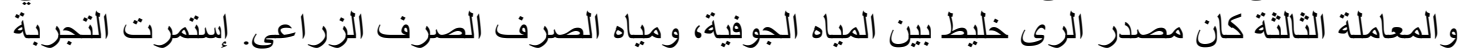

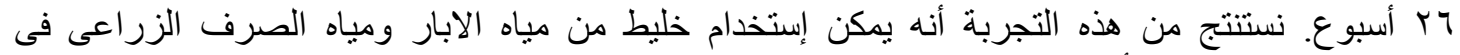

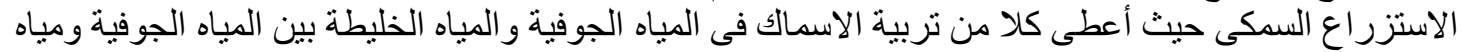

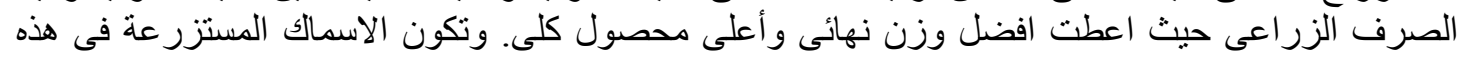
المياه امنة للإستهلاك الادمى من حيث منبقيات العناصر الثقيلة الثيلة. 